\title{
White Collar Crime dan Corporate Crime
}

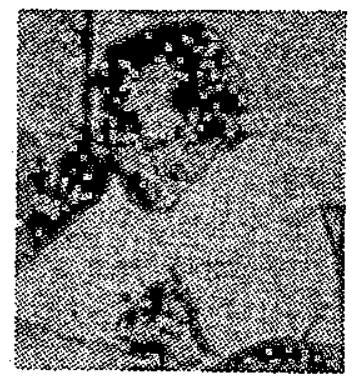

,

Artidjo Alkostar

White Collar Crime (WCC), pada naluriah dasarnya memang mencerminkan watak khas sebuah kejahatan, demikian halnya dengan

Corporate Crime, keduanya sama; sama merugikannya dan sama destruktifnya. Artidjo Alkostar menganalisis dalam tulisan ini.

White Collar Crime dan Korupsi Politik

WHITE COLLAR CRIME pertama kali diperkenalkan kepada umum oleh Edwin H. Sutherland pada tahun 1939, kendati sebelumnya Edward A. Ross secara sosiologis mengungkapkan adanya fenomena tingkah laku sosial yang dapat dikualifikasikan sebagai White Collar Crime. Tetapi term-term yang dipergunakan oleh Ross masih berada pada tataran pandangannya sebagai seorang sosiolog. Sedangkan, Sutherland telah lebih menukik sebagai kriminolog mengelaborasi White Collar Crime dengan menekankan kepada praktik-praktik kejahatan perdagangan yang ilegal di Amerika Serikat. Konseptualisasi tentang White Collar Crime yang digagas oleh Sutherland tersebut 'tersosialisasi hingga tahun 1960-an.

Sedangkan pada dasa warsa 1970-an yang disebut tahun-tahun depresi wadah pengartian tentang White Collar Crime jika dihubungkan dengan perkembangan fenomena sosial yang terjadi, maka yang terlihat tidak hanya masalah kebiasaan ilegal dalam hubungan kerja dan kendala-kendala dalam perdagangan tetapi sudah menyangkut pencemaran lingkungan, kecongkakan kelompok birokrasi yang tidak terkontrol, pengeluaran produk yang jelek pada masyarakat konsumen, intervensi pengaruh bisnis dalam politik luar negeri, dan lain sejenisnya. Dalam hal ini terlihat nuansa di masa kejahatan berkelompok yang merugikan kekayaan atau hak milik jauh lebih berat dari pelanggaran terhadap hak milik yang konvensional.

Fokus utama dari teori Sutherlan tentang White Collar Crime adalah kejahatan yang tertuju pada keuntungan ekonomis dalam usaha bisnis yang dilakukan secara ilegal dan di dalamnya menyangkut masalah manajemen. Kejahatan-kejahatan yang terjadi pada umum- nya dilakukan oleh para pekerja White Collar (kerah putih) untuk keuntungan pribadi pada waktu bekerja di perusahaannya, juga termasuk 
kejahatan suap dan melebihkan rekening yang seharusnya dibayar.

Dalam perspektif hukum dan kejahatan yang terjadi di Indonesia pada tahun 1970-an tersebut konsep tentang White Collar Crime tersebut dalam lingkaran interelasi antara penggelapan, korupsi dan suap. Dalam dekade tersebut, negara kita Indonesia sedang dilanda wabah korupsi yang sulit dicarikan obatnya. Terapi yuridis telah dicoba yaitu dengan memberlakukan undang-undang nomer 3 tahun 1971 yang mengancam koruptor dengan pidana maksimal seumur hidup penjara. Tetapi terapi yuridis tersebut hingga tahun 1994 ini tidak menunjukkan adanya efektivitas politik kriminalnya, karena kejahatan korupsi dengan berbagai corak dan variasinya masih menjadi penyakit sosial yang kronis sampai saat ini.

Sedangkan untuk menangkal dan memidana kejahatan yang menyangkut pencemaran lingkungan yang dilakukan oleh Konglomerat atau perusahaan di Indonesia baru mendapatkan legitimasinya dan diatur dalam undang-undang pada tahun 1982-an. Hingga saat ini permasalahan dan kasus-kasus yang menyangkut kejahatan pencemaran lingkungan ini terus menyita perhatian masyarakat banyak terutama yang menjadi korban pencemaran. Karena kasus atau perkara tentang pencemaran lingkungan ini di satu pihak menyangkut hak-hak dasar masyarakat untuk hidup aman dan bebas dari gangguan pencemaran lingkungan di pihak lain perusahaan, konglomerat, subyek hukum lain secara tidak bertanggung-jawab mencemari lingkungan yang pada saat bersamaan mendapatkan keuntungan materi atau penghematan biaya pengelolaan polusi yang ditimbulkan oleh pabriknya.

Menyeruaknya kasus tentang lemak babi di awal tahun 1990-an serta ramainya kasus Mie instan beracun 1994 ini, merupakan bagian tidak terlindunginya masyarakat konsumen di negara kita. Dalam arti pula, kejahatan White Collar, Crime yang menyangkut pengeluaran produk jelek ke tengah masyarakat dan merugikan atau membahayakan masyarakat belum mendapatkan atensi dan greget penang- gulangan yang serius hingga saat ini. Secara yuridis Undang-undang Kesehetan No. 23 tahun 1992 telah mengancam pidana penjara 15 tahun penjara dan denda sebanyak Rp. 300.000 .000 ,(tiga ratus juta rupiah) bagi barangsiapa mengedarkan makanan atau minuman yang tidak memenuhi standar dan atau persyaratan dan atau membahayakan kesehatan. Juga bagi barangsiapa yang memproduksi atau mengedarkan sediaan farmasi berupa obat atau bahan obat yang tidak memenuhi syarat farmakope Indonseia. Jadi dengan demikian terlihat bahwa kejahatan White Collar yang merugikan masyarakat konsumen Indonesia dan menyangkut makanan atau minuman serta obat-obatan baru diatur secara intensif dan dicanangkan untuk ditanggulangi secara nasional baru pada tahun 1992. Sedangkan konsumen untuk produk barang-barang lain (yang bukan makanan/minuman/obat-obatan) belum ada strategi penanggulangannya secara hukum, misalnya konsumen alat-alat elektronik, dan lain sebagainya.

Kalaulah White Collar Crime (WCC) secara konseptual diartikan sebagai "kejahatan kerah putih" untuk membedakan dengan kejahatan yang dilakukan oleh masyarakat pekerja kasar yang memakai "kerah biru" atau memakai jean maka dengan implementasinya menuntut evaluasi kritis. Dalam arti, bagaimana perlakuan hukum terhadap kejahatan kerah putih ini dibandingkan dengan perlakuan hukum terhadap penjahatan "kerah biru" yang pada umumnya lebih rentan secara ekonomis. Di negara kita Indonesia ada yang mencoba mengartikan WCC ini dengan "kejahatan priyayi", secara etimologis, istilah priyayi dapat berkonotasi dengan hal-hal yang feodalistis. Dan di negeri leluhurnya Amerika Serikat di mana istilah WCC ini lahir pernah juga diindikasikan adanya tingkatan kemunafikan atau kebohongan di dalam masyarakat (Amerika Serikat)-nya. Dalam arti pula, pada dasarnya apa yang dikatakan sebagai WCC itu adalah penipuan, kecurangan dan tipu muslihat dari masyarakat kelompok atas atau memakai kerah putih yang sebenarnya intinya sama dengan 
penipuan, tipu muslihat yang dilakukan oleh orang yang memakai kerah biru. Dalam hubungan ini terlihat adanya sikap "pandang bulu" perlakuan hukum terhadap apa yang dianggap WCC dibandingkan dengan apa yang diterima oleh yang dianggap bukan WCC.

\section{Kejahatan Korporasi}

\section{sebagai White Collar Crime}

Kejahatan korporasi atau Corporate Crime (CC) adalah kejahatan orang kantoran (White Collar Crime) dalam bentuk yang khsusus. Kejahatan korporasi dalam realitas kehidupan nasyarakat muncul dalam bentuk kejahatan yang terorganisäsi atau dilakukan oleh kelompok yang terdiri dari beberapa orang dalam kompleks hubungan-hubungan misalnya antara dewan direksi, direktur eksekutif dan manajer, atau hubungan di antara anak perusahaan, divisi-divisi dalam perusahaan dan cabang- cabang perusahaan.

Di negara kita Indonesia tahun 1990-an ini muncul fenomena-fenomena penyakit sosial yang mangarah atau tercakup dalam pengartian kejahatan koporasi ini misalnya munculnya kelompok usaha yang pada akhirnya diseret ke pengadilan karena dituduh dan dipersalahkan melakukan usaha bank gelap. Sedangkan trend semangat penanggulangan "bank gelap" dan sejenisnya ini baru mencuat sekitar waktu kelahiran undang-undang No. 71992.

Konsep dari kejahatan korporasi ini dikonstruksi agak umum, dan sering tumpang tindih dengan luasnya kawasan kejahatan dalam apa yang dinamakan pekerjaan atau profesi white collar. Sebagaimana dikemukakan di atas bahwa WCC dibedakan dengan kriminalitas kelas bawah dipandang dari segi struktur pelanggaran dan dalam kenyataannya terlihat bahwa sanksi perdata dan sanksi administratif lebih banyak dikenakan kepada pelaku WCC daripada sanksi pidana.

White Collar Crime dapat muncul dalam bentuk adanya pekerjaan (profesi) dan persekutuan (korporasi), sedangkan kejahatan profesi (pekerjaan) pada umumnya dilakukan secara individual atau kelompok kecil dari orang- orång yang berhubungan dengan pekerjaan mereka, misalnya businessman, dokter, ahli farmasi. Sehingga corak kejahatan mereka melekat pada corak pekerjaannya, misalnya menghindari pajak, memanipulasi penjualan produk. Dan di negara kita Indonesia saat ini menjadi fokus perhatian nasional tentang tindakantindakan pengusaha untuk menghindari pajak ini, bahkan dirjen pajak Fuad Bawazier pernah mengatakan bahwa banyak transaksi konglomerat lolos dari pungutan pajak (Suara Pembanian 1993).

Trend munculnya kasus-kasus yang mengindikasikan WCC di negara kita Indonesia meningkat kualitas maupun kuantitasnya, pada dasarnya menuntut upaya kritis untuk mengadakan penyegaran dan penajaman konsep tualisasi dari term-term kriminologi kita. Pada saat yang sama konsep-konsep yang responsif tersebut dapat dijadikan bahan-bahan untuk merekontruksi postulat-postulat moral dalam pembangunan hukum kita. Tanpa sadar akan tuntutan-tuntutan tersebut dan dimensi politik kriminil dalam hukum kita tidak efektif maka pada gilirannya masyarakat kita akan menjadi masyarakat kriminal.

\section{White Collar Crime di Negara Berkembang}

Kejahatan kerah putih di banyak negara berkembang menjadi penyakit masyarakat yang sangat serius dan memiliki dampak sosialpolitik luas. Kejahatan-kejahatan seperti korupsi, perbankan, konsumen, penyelundupan berjangkit secara kronis baik di Afrika, Asia, negara-negara Arab dan Amerika Latin. Fenomena tersebut dapat dilihat dari hasil penelitian dari UNSDRI (United Nations Social Defence Research Institute) -pada tahun 1987, dalam mana kejahatan-kejahatan yang menyangkut ekonomi dan termasuk dalam kategori White Collar Crime tersebut diungkapkan dalam tabel di halaman 6 .

Corak-corak kejahatan yang tersebut di dalam tabel hasil penelitian Badan Perserikatan Bangsa-Bangsa (PBB) tersebut di atas karakteristik pelakunya berkaitan langsung atau tidak langsung dengan orang-orang yang 
1986 - Regional ranking for specific economic crimes

\section{Africa}

$\begin{array}{lll}\text { Category } & \text { Rank } & \text { Sco } \\ & & \\ \text { Corruption } & 1 & 4.23 \\ \text { Bankruptcies } & 22 & 2.54 \\ \text { Consumer fraud } & 12 & 3.00 \\ \text { Smuggling } & 18 & 2.77\end{array}$

Asia

$\begin{array}{lll}\text { Category } & \text { Rank } & \text { Score } \\ \text { Corruption } & 10 & 3.00 \\ \text { Bankruptcies } & 16 & 2.40 \\ \text { Consumer Fraud } & 21 & 2.10 \\ \text { Smuggling } & 15 & 2.40\end{array}$

Arab States

Category : Rank

Score

4.23

Corruption

10

2.86

Bankruptcies

15

2.57

Consumer fraud

2.71

Smuggling

12

2.71

\section{Latin America}

Category

Rank

Score

Corruption

9

3.25

Bankruptcies

18

2.75

Consummer fraud 13

2.92

Smuggling

10

3.25

bekerja sebagai business people, anggota profesi dan pemerintahan, serta orang-orang yang melanggar kepercayaan yang diberikan kepadanya serta bekerja dengan jalan tidak etis atau mencederai kaidah hubungan moral.

Negara kita Indonesia sebagai negara berkembang di Asia juga tidak terkecuali dan termasuk dalam lingkup hasil penelitian tersebut, kendatipun variabel-variabel penyebab timbulnya kejahatan-kejahatan tersebut ada perbedaan dan nuansa yang melekat pada masing-masing negara. Dan sarjana Swedia Gunnar Myrdal dalam bukunya yang terkenal Asian Drama yang mengelaborasi terjadinya keculasan pegawai pemerintah di negara berkualifiksi "soft state", juga menunjukkan kebiasaan praktek suap menyuap dan keculasan pegawai pemerintah di negara-negara "lunak" tersebut berkolerasi dengan rezim pemerintahan yang otoriter.

Suburnya kasus suap menyuap dan White Collar Crime, di negara tetangga Indonesia dapat dilihat pada rezim pemerintahan Ferdinant Marcos di Filipina. Kasus-kasus tersebut tidak terlepas dari lemahnya kontrol hukum dan kontrol sosial politik, sehingga berbagai corak kolusi, nepotisme, pekerja profesi yang tidak etis, moralitas perbankan yang jelek akan menggejala dan merebak dengan tanpa adanya alternatif prefensi dan kontrol yang efektif. Di negara kita Indonesia saat ini juga tidak terkecuali apalagi kalau menyangkut bisnis anak pejabat atau bisnis konglomerat yang mendapat proteksi dari pejabat, terlihat dan dirasakan oleh nurani keadilan masyarakat bahwa kontrol hukum dan kontrol sosial politik sangat tidak efektif.

Kekhawatiran banyak pakar tentang melebarnya kesenjangan antara konglomerat dengan pengusaha kecil dewasa ini, dalam perspektif hukum sebenarnya merupakan konsekuensi dari rapuhnya moralitas hukum kita dalam realita tata pergaulan masyarakat kita saat ini. Katebelece seorang pejabat dapat mengalahkan kebenaran hukum, dan etos penegak hukum kita telah tampil dalam sosok yang lebih menonjolkan kekuasaan daripada moral kebenaran hukum. Sehingga kejahatan White Collar Crime dengan berbagai corak dan variasinya, menjadi tidak terkendali dan lepas dari kontrol hukum.

Kalau saat belakangan ini pemerintah Australia menyatakan bahwa korupsi dan sogok- 
menyogok antara perusahaan lokal dan internasional dengan pemerintah negara-negara Pasifik Selatan telah ikut merusak lingkungan alam (Kompas, 4/8/94), maka hal itu memberi gambaran bagi kita bahwa kolusi yang bermuatan white collar crime mempunyai implikasi langsung dengan perusakan lingkungan alam dan penghancuran sumber daya alam, di samping pengrusakan mental masyarakat. Pernyataan pemerintah Australia tersebut dikemukakan pada pembukaan pertemuan ke-25 Forum Pasifik Selatan yang beranggotakan 15 negara.

Kejahatan para pengusaha dalam menjalankan roda bisnisnya dengan cara jalan pintas dan berkolusi dengan penguasa, pada dasarnya melakukan praktek-praktek yang tidak fair dan melecehkan prosedur-prosedur yang sah. Dengan cara penyuap penguasa, para pengusaha white collar dengan sengaja melawan hukum untuk memperoleh keuntungan yang sebesarbesarnya tanpa memperdulikan etika bisnis dan pihak lain yang tidak menyuap. Jadi, kejahatan white collar crime pada dasarnya tumbuh dari sikap egois, tidak etis dan serakah, serta merusak kaidah tata hubungan sosial masyarakat. Dalam hubungan ini, penyakit white collar crime tidak hanya diidap oleh negara-negara berkembang atau negara-negara lunak, tetapi juga bisa menyerang tubuh pemerintahan negara maju, termasuk Amerika Serikat, Jepang, Italia, Jerman dan sejenisnya.

Di negara Italia misalnya, hasil penyelidikan menunjukkan baha $71 \%$ suap dilakukan oleh pengusaha kecil, selain juga dilakukan oleh pengusaha menengah (Jawa Pos, 6/8/94), kendati pun di negara tersebut telah dilakukan operasi "Clean hands". Dan ironisnya, kerugian uang negara lebih besar dari sebelum dilancarkan operasi "tangan-tangan bersih" tersebut. Hal ini menunjukkan betapa dalam suatu operasi pemberantasan white collar crime itu perlu lagi dibentuk tim yang mengawasi petugas operasi tersebut. Kondisi yang demikian menunjukkan terjadinya situasi yang tragikomis, di mana pengawas perlu diawasi. Seperti halnya juga di negara kita saat ini, di mana sering terjadi polisi yang dipolisi-i, jaksa yang dijaksai, hakim yang dihakimi dan penasihat hukum yang perlu diberi nasihat hukum. Bahkan belakangan ini gencar tuntutan-tuntutan terhadap laksamana Sudómo yang dulu gencar melakukan operasi penertiban (Opstib), agar Sudomo yang memberi katebelece kepada Edy Tansil dan merugikan uang negara 1,3 trilyun itu diopstib.

Merajalelanya penyakit white collar crime dan corporate crime dapat menimbulkan krisis kewibawaan pemerintah, karena mental aparatnya dapat dibeli atau ditukar dengan barang sesuatu milik pengusaha. Dalam proses dan upaya penanggulangan white collar crime dan corporate crime, para penegak hukum dituntut untuk menunjukkan kecermatan dan kecerdasannya, terutama dalam praktek peradilannya, dari sejak penyelidikan, penyidikan serta penuntutannya. Dalam arti pula, dalam menuntut dan membuktikan di muka pengadilan kasus white collar crime dan coporate crime, tidak semudah menuntut dan membuktikan kasus perampokan. Lebih dari itu, kejahatan white collar crime dan corporate crime memiliki berbagai corak dan variasi, bahkan seorang kriminolog Amerika Serikat James A. Inciardi, dalam mengelaborasi tentang white collar crime dan corporate crime, antara lain menunjukkan aktivitas kerja pada tiap-tiap sektor, misalnya dengan menyebut:

1. In the bussiness sector financial manipulation, unfair labor pratices, rebates, misrepresentation of goods and consumer diseption by false labeling, fancing of stoleh goods, shortchanging, over charnging black-marketing.

2. In the labour sector misuse of union funds, failing to inforce laws affecting unions, entering in to collusion with emploeyers to the disadventage of union members, illegal mechanisms for controling members.

3. In the corporate sector restraing of trade, infrigemant of patents, monopolistic practices, environmental contamination, misuse of trade marks, manufakture of unsefe goods, false advertising, disposal of toxise wastes. 
4. In the financial sector embezzlement, violation of currency control measures, stock manipulation.

5. In the medical sector illegal prescription practices, fee-splitting, illegal, abortions, fraudulent reports to insurance companies.

6. In the legal sector misappropriation of funds in trust and receiverships, securing prejudice testimony, bribery, instituting fraudulent damage claims.

7. In the criminal justice sector accepting bribes, illegal arrest and detention practices, illegal correctiobal practices.

8. In the civil sector illegal commissions, issuance of fraudulent licenses and certificates, illegal tax evaluations, misuse of campaign funds, allegal campaign practoces.

Dari apa yang dipaparkan oleh kriminolog James A. Inciardi tersebut di atas, terlihat bahwa white collar crime dan corporate crime dapat berjangkit dibeberapa kantong-kantong aktivitas masyarakat, yaitu sektor bisnis, perburuan, perusahaan, keuangan, kesehatan, hukum, penegak hukum pidana, dan masyarakat.

Terjadinya kasus-kasus kejahatan di negara kita saat ini, antara lain pabrik atau perusahaan yang merugikan konsumen, perusahaan yang memperlakukan dan membayar buruk secara tidak layak, praktek-praktek monopoli, kasus pemalsuan sertifikat di Bursa Efek Jakarta, praktek pengguguran kandungan, penyuapan dalam dunia peradilan, kasus mengkaryakan nara pidana secara ilegal, pemalsuan sertifikat tanah, dan lain sebagainya menunjukan betapa white collar crime dan corporate crime telah merasuk dan berjangkit di berbagai sektor dan institusi swasta maupun pemerintah di negara kita saat ini. Dalam arti pula, keberadaan dan peran hukum di negara kita tengah "digugat" oleh masyarakat.

Artidjo Alkostar, SH. adalah staf pengajar FH UII, Kepala pada LPM UII serta seorang advokat. Alumnus .Fakultas Hukum UII Yogyakarta.

Sumber dan referensi:

- Clinard, Marshall B \& Yeanger, Peter C. Corporate Crime, The Free Press, New York 1990.

- Geis, Gilbert \& Meier, Robert F. White Collar Crime, The Free Press, New York 1977.

- Inciardi, James A. Criminal Justice, Harcourt Brace Jovanovich, Inc., San Diego, 1987.

- Myrdal, Gunnar, Asian Drama, The Twentieth Century Fund, New York, 1971. 